\section{Assessing the habitat conservation status by soil parameters and plant ecoindicators}

\author{
Flavia Sicuriello $^{(1-2)}$, Cristina De Nicola ${ }^{(3)}$, Giuseppina Dowgiallo ${ }^{(3)}$, \\ Anna Testi ${ }^{(3)}$
}

The aim of this study was to assess the conservation status of a Natural Re serve located in central Italy through an integrated analysis including soil, lithotype and edaphic parameters, landforms, and plant species. The relationships between soil and vegetation was investigated using soil variables and plant ecoindicators, expressed by: (i) the Ellenberg's bioindication model; and (ii) the Hemeroby Index. Vegetation and soil data have been collected in thirty vegetation relevés and soil profiles. Cluster analysis, performed on a matrix 12 variables / 30 relevés allowed the detection of two main clusters, each divided into sub-clusters, characterized by peculiar floristic composition and soil characteristics. Clusters were markedly discriminated by soil Available Water Capacity (AWC). Canonical Correspondence Analysis (CCA) performed on variables and species matrices allowed to separate two main habitats: (i) a core habitat represented by patches of temperate forest correlated to soil cycles of water and nutrients; (ii) an ecotonal habitat composed by mixed evergreen and thermophilous deciduous oak forest, mainly related to the light, temperature and human disturbance regimes.

Keywords: Mediterranean Forest Vegetation, Soil, AWC, Ellenberg's Indicators, Hemeroby Index, CCA

\section{Introduction}

The assessment of habitat conservation status, especially in protected areas, is nowadays one of the main tasks of local, national and international offices attending to nature conservation and management. In this context, recent studies in applied ecology focused on methods based on ecoindicators for habitat survey and monitoring. The usefulness of ecoindicators is well known (Cairns et al. 1993), in particular for the early detection of trends in ecological factors such as climate, soils and disturbances (Fanelli \& Testi 2008, Hill et al. 2002).

The main challenge in applied ecology is the identification of the key factors involved in the response of species and communities to disturbances and in their ecological structure (Fanelli et al. 2006a, Borhidi 1995). Focusing on the relationship between soil and vegetation, static factors such as soil $\mathrm{pH}$ and texture, soil carbon and nitrogen stock, exchangeable bases, etc. can be easily measured by soil profiles and laboratory analyses. Instead, dynamic factors like mineralization rate, water availability and annual average temperature, etc. are harder to be obtained without long-term research efforts (Schimel \& Bennet 2004). Nonetheless, the above factors may be easily assessed by the use of plant ecoindicators, such as Ellenberg's indicators (Ellenberg 1974, Testi et al. 2006, Diekmann 1995) and Hemeroby Index for the anthropic disturbance evaluation (Kowarik 1990). Using the above indexes, the detection of changes in species and communities along spatio-temporal gradients and at different scale levels have been successfully carried out (Angermeier \& Karr 1994, Lalanne et al. 2010, Hillebrand 2005).

Ellenberg's indicator values (EIVs) express through a numerical value the average reali-

$\square$ (1) Department of Forest Environment and Resources, University of Tuscia, v. S. Camillo de Lellis snc, I-01100 Viterbo (Italy); (2) IBAF-CNR, v. Salaria km 29.3, I-00016 Monterotondo Scalo (RM - Italy); (3) Department of Environmental Biology, Botanical Garden, "La Sapienza” University of Rome, l.go Cristina di Svezia 24, I-00165 Rome (Italy)

@ Flavia Sicuriello (flavia.sicuriello@ibaf.cnr.it)

Received: Feb 01, 2013 - Revised: Jul 30, 2013 - Final Acceptance: Dec 3, 2013

Citation: Sicuriello F, De Nicola C, Dowgiallo G, Testi A, 2014. Assessing the habitat conservation status by soil parameters and plant ecoindicators. iForest 7: 170-177 [online 2014-02-14] URL: http://www.sisef.it/iforest/contents/?id=ifor0963-007

Communicated by: Raffaele Lafortezza

zed niches along seven fundamental gradients (light, temperature, continentality, soil moisture, soil $\mathrm{pH}$, nutrients, salinity). EIVs summarize in scales with nine degrees (up to twelve for soil moisture indicator) the large amount of ecological information on plants and plant communities associated with environmental measurements of edaphic and climatic parameters. Limitation and strengths of the Ellenberg's approach have been long debated (e.g., Ewald 2003), though a number of studies showed a good agreement between indicators and environmental variables (e.g., Fanelli et al. 2007, Schaffers \& Sykora 2000, Schmidtlein \& Ewald 2003, Southall et al. 2003, Kaiser \& Käding 2005). EIVs represent a first model of bioindication applied for the first time to the flora of Germany (Ellenberg 1974), and then extended to Netherlands (van der Maarel et al. 1985), Norway (Vevle \& Aase 1980), Sweden (Diekmann 1995), Estonia (Pärtel et al. 1996, 1999), Poland (Roo-Zieliska \& Solon 1988), Great Britain (Hawkes et al. 1997), northeastern France (Thimonier et al. 1994) and Italy (Celesti Grapow et al. 1993, Pignatti 2005, Fanelli et al. 2006b). EIVs have been shown to successfully describe the ecological patterns of plant communities and to be related to important functional traits (Schaffers \& Sykora 2000, Pignatti et al. 2001, Testi et al. 2004). They are mainly used for environmental monitoring (Ellenberg et al. 1992), and in ecological studies for the interpretation of ordinations in terms of known gradients (Grime et al. 1988). EIVs have been largely applied in botanical studies (Van der Maarel 1975, Diekmann 1995) and more recently in ecological investigations (Testi et al. 2012, Godefroid et al. 2007, Jones et al. 2007).

Closely related to EIVs is the hemeroby index $(\mathrm{H})$ which is related to the degree of past and present human impacts on ecosystems according to a ten-point scale (Van der Maarel 1975, Kowarik 1990, Fanelli \& De Lillis 2004). Direct estimation of disturbance and human impact is usually difficult. However, hemeroby index has been successfully applied in studies based on changes in the composition of communities and species in order to assess the response of vegetation to disturbance (Fanelli \& Testi 2008).

The ecosystemic approach based on ecological indicators described above is particularly useful in the assessment of the conservation status of forest habitats that are increasingly threatened by human activities and urban sprawl, like in the surrounding of large cities. The aim of this study is to evaluate the conservation status of a natural reserve in the surroundings of Rome (Italy) through an integrated approach, analysing simultaneously soils, lithotypes, landforms, edaphic parameters and plant species. 


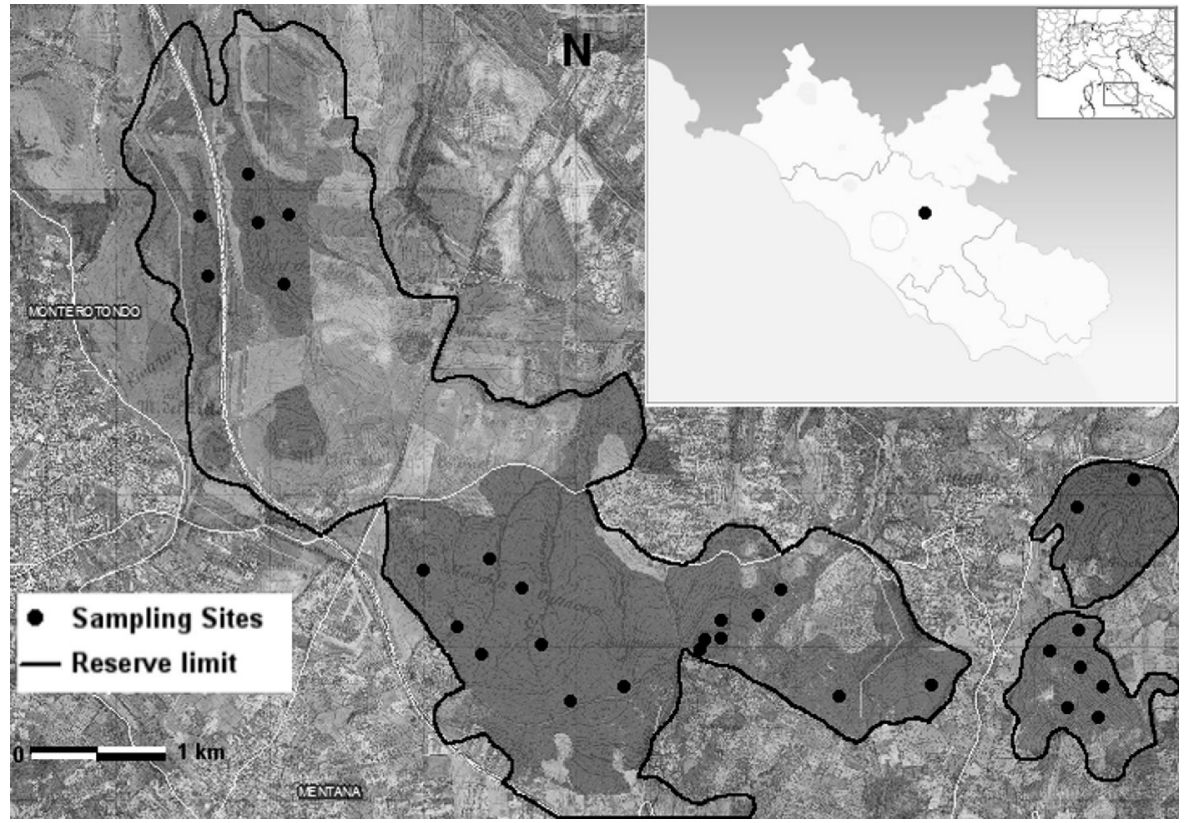

Fig. 1 - The study area (Regional Reserve "Macchia di Gattaceca e Macchia del Barco").

\section{Materials and methods}

\section{Description of the study area}

The "Macchia di Gattaceca e Macchia del Barco" natural reserve, established in 1997, is located in the Province of Rome, between the Tiber Valley and the Lucretili Mountains (UTM N $42^{\circ} 05^{\prime}$, E $12^{\circ} 50^{\prime}$ - Fig. 1). The protected area covers about 1000 hectares of forested hills, with altitude ranging between 78 and $241 \mathrm{~m}$ a.s.l. The area was subjected to a long-term historical disturbance, due to heavy cutting and burning, as well as to grazing, which has been recently restricted to some edge zones only.

From the geological point of view, the area is mainly made up of Mesozoic limestone formations of the Tiber Ridge (Soratte Mt Cornicolani Mts), referring to the UmbroSabina succession. Since Pliocene, marine ingression/regression led to the deposition of yellow sand, calcareous conglomerates, clayey sand and yellowish clay, until the final emergence of the whole area in the Pleistocene (Martinis 1992). Pleistocenic pyroclastic products from the Sabatino and Laziale volcanic districts were then deposited (Anonymous 1993). Limestones in the area show intense fracturing and karst phenomena with numerous sink-holes, including Pozzo del Merro, the deepest explored sink-hole in the world (-392 m a.s.l. - Gary et al. 2003). Geological heterogeneity in the area is one of the causes of its geomorphological diversity, dolines, ditches, plains, slopes make the environmental mosaic.

The most widespread vegetation is a deciduous mixed oak forest, dominated by Quercus cerris and Quercus frainetto, codominants in some sites. Quercus robur is present in the diches, while Quercus pubescens and Quercus ilex shrublands are present on sunny calcareous slopes (Dowgiallo \& Vannicelli 1993, Testi et al. 2000).

Climate is moderately Mediterranean with about 2 months drought in summer (July and August); average yearly temperature is 15.2 ${ }^{\circ} \mathrm{C}$ and annual rainfall $813 \mathrm{~mm}$, with two peaks in October-November and April (Fig. 2). As for the pedoclimate (USDA 2010), temperature regime resulted to be Thermic. The soil moisture regime is Xeric for most of
Fig. 2 - Climogram of the meteorological Guidonia-

Montecelio station (89 $\mathrm{m}$ a.s.l.) nearby to the study area. Monthy means for the period 1971-2000.

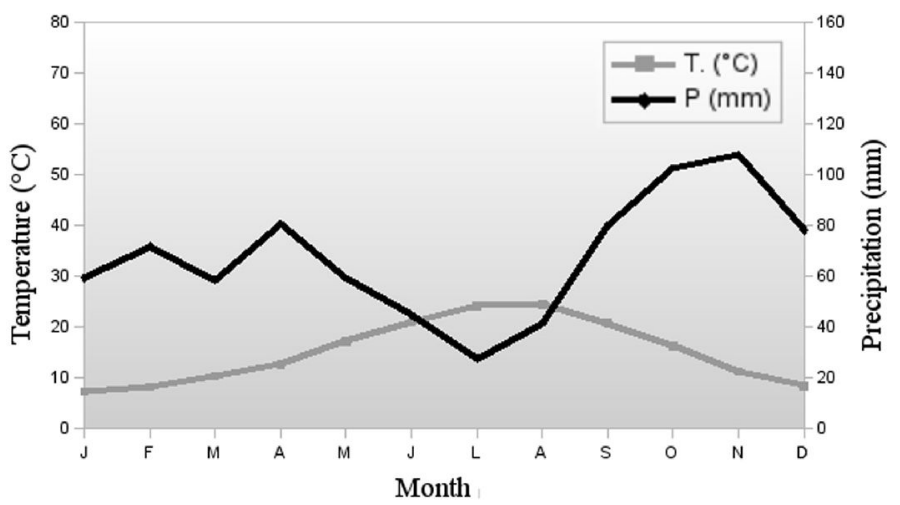

the studied soils. Only soils on plio-pleistocenic sediments with the highest available water capacity have Udic moisture regime.

\section{Field data collecting and analysing}

Thirty sampling sites, each of $100 \mathrm{~m}^{2}$, were chosen using randomized-systematic method (Gillet 2000, Podani 2007). Samplings were distributed over the whole study area within the following geomorphological units:

- Unit A: ridges (6 samplings),

- Unit B: mountain slopes (6 samplings),

- Unit C: plain surfaces (6 samplings),

- Unit D: ditches, subdivided into D1ditches bottom (4 samplings), D2-ditches gentle slopes (4 samplings) and D3-ditches steep slopes (4 samplings).

In each site phytosociological relevés and soil profiles were carried out simultaneously.

\section{Vegetation}

Phytosociological relevés were carried out using Braun-Blanquet method (Braun-Blanquet 1932, Westhoff \& Van der Maarel 1978). All vascular plant species were determined in each site and their relative coverage recorded on a percentage basis. Nomenclature of species followed Pignatti (1982) revisited with MedCheckList (Greuter et al. 1984). Overall, a floristic matrix of 130 species x 30 relevés was obtained.

\section{Ecoindicators}

Ellenberg's Indicator Values (EIVs - Ellenberg 1974, Ellenberg et al. 1992) and Hemeroby Index (Kowarik 1990) were applied in this study. The full list of the indicators applied was as follows: (1) L: light; (2) T: temperature; (4) F: soil moisture; (5) R: soil reaction; (6) N: soil nitrogen; (7) hemeroby. Since salinity (S) is used only for saline soils and continentality $(\mathrm{K})$ has a meaning only on a geographical scale, these two indicators were excluded from the analysis.

All the above indexes were weihted on species coverage.

\section{Pedological analysis}

In each sampling site soil profiles were obtained and described following the guidelines for Soil Survey by Costantini (2007). Seventy seven samples were collected and analysed with standard methods (MIPAF 2000) for: (i) texture; (ii) $\mathrm{pH}$ in a 1:2.5 soil/ water suspension; (iii) total carbonates; (iv) organic carbon and organic matter; (v): exchangeable acidity; (vi): exchangeable bases; (vii): cation exchange capacity; (viii) total nitrogen; (v) available phosphorus. Moreover, three additional parameters were calculated: available water capacity (AWC), base saturation and carbon/nitrogen ratio $(\mathrm{C} / \mathrm{N})$. Available water capacity (AWC, $\mathrm{mm} \mathrm{H}_{2} \mathrm{O}$ $\mathrm{cm}^{-1}$ soil depth) was estimated by the Salter $\&$ Williams (1969) equation based on textural composition and percentage of organic 
matter (eqn. 1):

$$
\begin{gathered}
A W C=1.475-0.010 \cdot C S \\
+0.011 \cdot S+0.138 \cdot O C
\end{gathered}
$$

where $C S$ is the percentage of the coarse sand, $S$ is the percetage of silt and $C O$ is the percentage of organic carbon in the sample.

Although all soil horizons were sampled and analysed separately, statistical analysis was applied on weighted averages, calculated by multiplying the value of each parameter by the horizon thickness, summing these values and dividing them by the total depth of the profile (Daniels et al. 2004, Feng et al. 2009, Benbi \& Brar 2009).

Soils were classified to the subgroup level according to the Soil Taxonomy (USDA 2010).

\section{Statistical treatment}

For each one of the 30 sites studied, values were obtained for 12 variables: 6 ecoindicators and 6 soil parameters (Tab. S1 in Appendix 1). All variables were normalized and standardized (since having different scales and units) by subtracting the variable mean and dividing by their standard deviation (Podani 2007).

The following multivariate statistical analyses were applied on standardized variables: (i) cluster analysis (CA) on the variables/ relevés matrix $(12 \times 30)$; (ii) Canonical Correspondence Analysis (CCA) on the whole data set (variables/relevés $12 \times 30$ and species/relevés 130x30 matrices).

All statistical analyses were performed by the software R (R Development Core Team 2012) using the package "vegan" for community ecology (Oksanen et al. 2012), "cluster" for cluster analysis (Maechler 2012) and "ecodist" for distance calculation (Goslee \& Urban 2007).

To recognize the main gradients in the dataset, normalized variable scores were calculated from their weights on CCA axes. To test the significance of species/environmental factors correlation, two-ways ANOVA with permutation was performed on the CCA model, variables and axes (Legendre \& Legendre 1998). Using the R package "anova.cca" the number of permutations is controlled by targeted "critical" $P$ value and accepted Type II or rejection error $(\beta)$; permutations were performed until the $P$ value obtained differs from the targeted $\alpha$ at risk level given by $\beta$.

Analysis of variance (one-way ANOVA) was performed on clusters obtained by CA to test for possible differences in soil parameters and ecoindicator means.

\section{Results}

Cluster Analysis

Results of the cluster analysis carried out

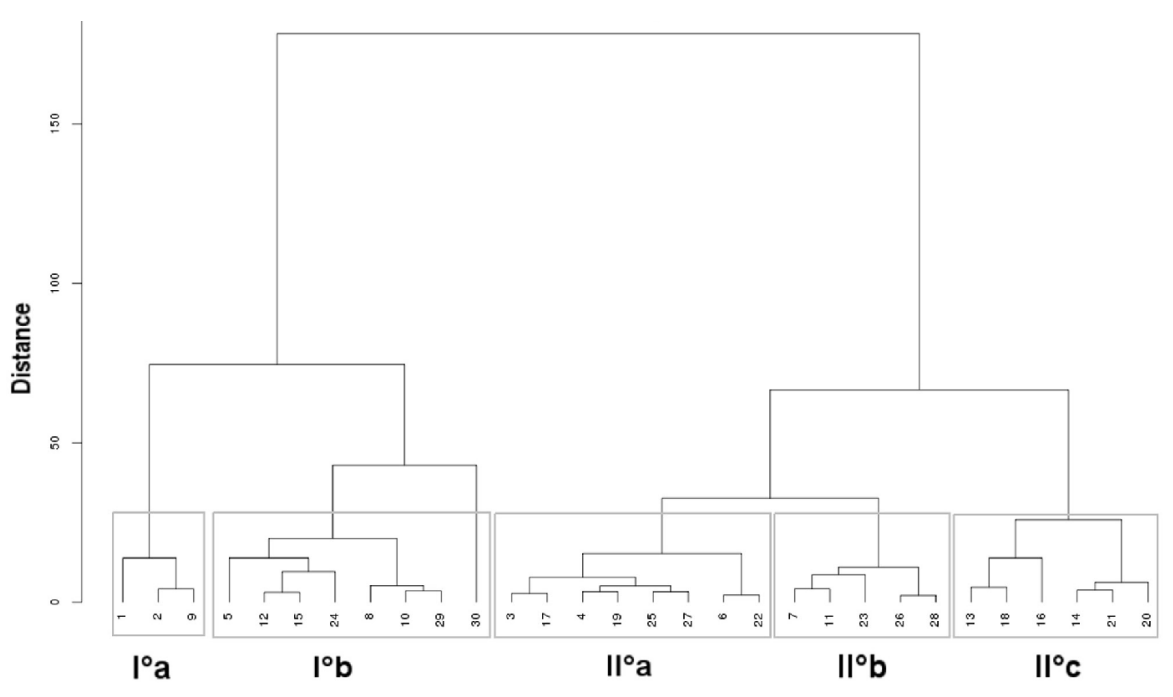

Fig. 3 - Dendrogram of the relevés from the cluster analysis carried out on the matrix of 12 variables (6 ecoindicators and 6 soil parameters) x 30 sites. Two main clusters are outlined, each one further distinguished into sub-clusters. on the variables/relevés matrix revealed the existence of two main groups of relevés (Fig. 3 ), each one divided into sub-clusters, distinguished by floristic (Table S2 in Appendix 1), ecological (Ellenberg's indicators) and edaphic characteristics. Overall, 5 clusters were identified $\left(\mathrm{I}^{\circ} \mathrm{a}, \mathrm{I}^{\circ} \mathrm{b} ; \mathrm{II}^{\circ} \mathrm{a}, \mathrm{II}^{\circ} \mathrm{b}, \mathrm{II}^{\circ} \mathrm{c}\right.$ - see Tab. 1). Vegetation, soil types, bedrocks and geomorphological units of the sampled areas are summarized in Tab. 2. Following is a brief description of the two main clusters and the five subclusters identified.

$I^{\circ}$ cluster: Thermophilous submediterranean /mediterranean woodlands and shrublands with Quercus cerris along with Quercus ilex and Quercus pubescens (locally dominant) on calcareous rocks, lithic soils. Geomorphological units are ridges (A) and mountain tops (B).

- $I^{\circ}$ a sub-cluster: sclerophyllous shrublands dominated by Quercus ilex, with Viburnum tinus on the ridges.

- $I^{\circ} b$ sub-cluster: open woodlands and shrublands of Quercus pubescens and
Quercus ilex along with Mediterranean species (such as Pistacia terebinthus, Phyllirea latifolia and Cercis siliquastrum) on moderately to strongly steep slopes.

II ${ }^{\circ}$ cluster: Mesophilous and hygrophilous woodlands dominated by Quercus cerris and Quercus frainetto with the occurrence of Quercus robur on deep and very deep soils on plio-pleistocenic marine sediments (slopes of ditches and gorges), tuffs (gentle slopes) and calcareous rocks (depressions and gentle slopes). This vegetation type is the most common in the study area. Geomorphological units are plain surfaces (C) and ditches (D).

- $I I^{\circ}$ a sub-cluster: mesophilous woodlands with Quercus robur on tuffs.

- $I I^{\circ} b$ sub-cluster: hygrophilous woodlands with Quercus robur, Acer obtusatum, Ulmus minor, Sambucus nigra and Corylus avellana on marine sediments and calcareous bedrocks and soils with the highest AWC values (Tab. 1).

- $I I^{\circ} \mathrm{C}$ sub-cluster: more open woodlands
Tab. 1 - Mean values ( \pm standard deviations) of soil parameters and ecoindicators in the 5

\begin{tabular}{|c|c|c|c|c|c|}
\hline Parameters & $I^{\circ} \mathbf{a}$ & $\mathbf{I}^{\circ} \mathbf{b}$ & II $^{\circ} \mathbf{a}$ & $\mathbf{I I}^{\circ} \mathbf{b}$ & II $^{\circ} \mathbf{c}$ \\
\hline $\mathrm{pH}$ & $7.8 \pm 0.5$ & $7.2 \pm 0.5$ & $6.4 \pm 0.7$ & $7.6 \pm 0.8$ & $6.8 \pm 1$ \\
\hline $\mathrm{CaCO}_{3}(\%)$ & $0.3 \pm 0.5$ & $1.4 \pm 4$ & $0.1 \pm 0.1$ & $3.4 \pm 4.4$ & $0.1 \pm 0.2$ \\
\hline $\operatorname{Org}(\%)$ & $2.8 \pm 0.4$ & $4.3 \pm 1.3$ & $2.5 \pm 0.8$ & $3.3 \pm 0.1$ & $1.4 \pm 0.5$ \\
\hline $\mathrm{N}(\%)$ & $0.2 \pm 0$ & $0.5 \pm 0.2$ & $0.3 \pm 0.1$ & $0.3 \pm 0$ & $0.2 \pm 0.1$ \\
\hline $\mathrm{C} / \mathrm{N}$ & $11.5 \pm 2.1$ & $8.9 \pm 1.4$ & $8.9 \pm 1.5$ & $10.3 \pm 0.8$ & $8.6 \pm 1.7$ \\
\hline $\mathrm{AWC}(\mathrm{mm})$ & $137 \pm 6.9$ & $98 \pm 14$ & $219 \pm 5.1$ & $240 \pm 6.3$ & $195 \pm 9.7$ \\
\hline $\mathrm{H}$ & $2.7 \pm 0.4$ & $2.6 \pm 0.6$ & $2.5 \pm 0.4$ & $2.3 \pm 0.1$ & $2.3 \pm 0.2$ \\
\hline $\mathrm{L}$ & $3.7 \pm 0.5$ & $4.3 \pm 1$ & $3.4 \pm 0.3$ & $3.5 \pm 0.4$ & $3.3 \pm 0.1$ \\
\hline $\mathrm{T}$ & $7 \pm 0.6$ & $7 \pm 0.6$ & $6.4 \pm 0.3$ & $6.6 \pm 0.3$ & $6.4 \pm 0.3$ \\
\hline $\mathrm{F}$ & $5.3 \pm 0.6$ & $5.3 \pm 0.7$ & $5.9 \pm 0.2$ & $5.8 \pm 0.4$ & $5.9 \pm 0.2$ \\
\hline $\mathrm{R}$ & $7.2 \pm 0.3$ & $7.4 \pm 0.1$ & $7.3 \pm 0.2$ & $7.4 \pm 0$ & $7.4 \pm 0.1$ \\
\hline $\mathrm{N}$ & $5 \pm 1.2$ & $5.4 \pm 0.8$ & $6.1 \pm 0.4$ & $5.9 \pm 0.4$ & $6.2 \pm 0.3$ \\
\hline
\end{tabular}
groups identified by cluster analysis. 
Tab. 2 - Integrated table of geomorphological units, bedrocks, soil types and vegetation following sub-clusters.

\begin{tabular}{|c|c|c|c|c|}
\hline Subcluster & Bedrocks & Land Forms & Dominat soil types & Dominat tree species \\
\hline $\mathrm{I}^{\circ} \mathrm{a}$ & $\begin{array}{l}\text { Calcareous } \\
\text { rocks }\end{array}$ & A-ridge & $\begin{array}{l}\text { TYPIC HAPLOXEREPTS: } \\
\text { fine, thermic, superactive. Shallow soils, with low water availability } \\
(<140 \mathrm{~mm}) \text {. Clay. Neutral to weakly alkaline slightly calcareous. } \\
\text { Very high E.C.C. }(40-50 \mathrm{cmol} / \mathrm{kg}) \text { and very high Base Saturation } \\
(80-90 \%)\end{array}$ & $\begin{array}{l}\text { Quercus ilex } \\
\text { Quercus pubescens } \\
\text { Quercus cerris }\end{array}$ \\
\hline $\mathrm{I}^{\circ} \mathrm{b}$ & $\begin{array}{l}\text { Calcareous } \\
\text { rocks }\end{array}$ & $\begin{array}{l}\text { B-mountain } \\
\text { slope }\end{array}$ & $\begin{array}{l}\text { LITHIC HAPLOXEROLLS: } \\
\text { fine, thermic, superactive. Shallow soils, stony, with rather low } \\
\text { water availability }(<110 \mathrm{~mm}) \text {. Clay loam- clay. Weakly alkaline. } \\
\text { Slightly calcareous or acalcareous. Very high E.C.C. }(50-70 \\
\text { cmol/kg) and very high Base Saturation }(>90 \%) \text {. }\end{array}$ & $\begin{array}{l}\text { Quercus ilex } \\
\text { Quercus pubescens } \\
\text { Quercus cerris }\end{array}$ \\
\hline $\mathrm{II}^{\circ} \mathrm{a}$ & Tuffs & $\begin{array}{l}\text { D2-ditches } \\
\text { gentle slopes } \\
\text { C-plain surfaces }\end{array}$ & $\begin{array}{l}\text { TYPIC HAPLOXEREPTS, MOLLIC/TYPIC HAPLOXERALFS: } \\
\text { fine, thermic, active. Shallow to moderately deep soils, with } \\
\text { moderate to high water availability ( } 210 \text { to } 220 \mathrm{~mm}) \text {. Weakly acid. } \\
\text { Silty clay to clay. High E.C.C. and high Base Saturation ( } 60-75 \%) \text {. }\end{array}$ & $\begin{array}{l}\text { Quercus cerris } \\
\text { Quercus frainetto }\end{array}$ \\
\hline $\mathrm{II}^{\circ} \mathrm{b}$ & $\begin{array}{l}\text { Plio-pleisto- } \\
\text { cenic marine } \\
\text { sediments } \\
\text { and calca- } \\
\text { reous rocks }\end{array}$ & $\begin{array}{l}\text { D2-ditches } \\
\text { gentle slopes } \\
\text { D1-ditches } \\
\text { bottom }\end{array}$ & $\begin{array}{l}\text { ENTIC HAPLUDOLLS: } \\
\text { fine silty, thermic, superactive. Very deep soils, with very high } \\
\text { water availability }(230-250 \mathrm{~mm}) \text { and udic moisture regime. Silt } \\
\text { loam. Moderately alkaline, weakly to moderately calcareous } \\
(2-14 \% \text { CaCO3). Very high E.C.C. }(60-70 \mathrm{cmol} / \mathrm{kg}) \text { and very high } \\
\text { Base Saturation }(100 \%) \text {. }\end{array}$ & $\begin{array}{l}\text { Quercus cerris } \\
\text { Quercus frainetto } \\
\text { Quercus robur }\end{array}$ \\
\hline $\mathrm{II}^{\circ} \mathrm{c}$ & $\begin{array}{l}\text { Calcareous } \\
\text { rocks }\end{array}$ & $\begin{array}{l}\text { D1-ditches } \\
\text { bottom } \\
\text { C-plain } \\
\text { surfaces }\end{array}$ & $\begin{array}{l}\text { ULTIC HAPLOXERALFS and TYPIC EUTRUDEPT: } \\
\text { fine, thermic, active. Deep soils with very high water availability } \\
(>200 \mathrm{~mm}) \text {. Silty clay - clay. Moderately to weakly acid. High } \\
\text { E.C.C. }(40 \text { to }>50 \mathrm{cmol} / \mathrm{kg}) \text {, high Base Saturation }(60-70 \%) \text {. }\end{array}$ & $\begin{array}{l}\text { Quercus cerris } \\
\text { Quercus frainetto } \\
\text { Quercus robur }\end{array}$ \\
\hline
\end{tabular}

characterized by large cover of Prunus spinosa and exclusive occurrence of ruderal and edge species, such as Onopordum illyricum, Bellis perennis, Dactylis glomerata, Holcus lanatus on calcareous rocks.

\section{Analysis of variance}

Significant differences among the five subclusters identified were detected for the variable AWC after one-way ANOVA ( $\mathrm{df}=4$; $\mathrm{SS}=92959.3 ; \mathrm{F}=252.2, \mathrm{P}<0.0001)$. To test

the significance of differences among subclusters' means, Fisher LSD test was carried out $(\mathrm{P}<0.05)$. Results showed that subcluster $\mathrm{I}^{\circ} \mathrm{a}$ and $\mathrm{I}^{\circ} \mathrm{b}$ had means significantly lower than the mean of the other three subclusters $\left(\mathrm{II}^{\circ} \mathrm{a}, \quad \mathrm{II}^{\circ} \mathrm{b}, \quad \mathrm{II}^{\circ} \mathrm{c}\right)$. Sub-cluster $\mathrm{I}^{\circ} \mathrm{b}$ showed that means for ecoindicator $\mathrm{L}$ $(\mathrm{DF}=4, \mathrm{SS}=4.44 ; \mathrm{F}=3.39, \mathrm{P}<0.024)$, organic carbon $(\mathrm{DF}=4, \quad \mathrm{SS}=31.49 ; \quad \mathrm{F}=11.14$, $\mathrm{P}<0.0001)$ and nitrogen $(\mathrm{DF}=4, \mathrm{SS}=0.42$; $\mathrm{F}=5.29, \mathrm{P}<0.003)$ were significantly higher

Tab. 3 - CCA Outputs. (1) Partitioning of mean squared contingency coefficient; (2) Eigenvalues and their contribution to the mean squared contingency coefficient (first three axes); (3) Biplot scores for constrained variables. $\left.{ }^{*}\right)$ : $\mathrm{p}<0.05$; (**) $\mathrm{p}<0.01$; (***): $\mathrm{p}<0.001$.

\begin{tabular}{lccc}
\hline Output 1 & Inertia & Proportion & Rank \\
\hline Total & 3.768 & 1 & - \\
Constrained & 2.505 & 0.665 & 13 \\
Unconstrained & 1.263 & 0.335 & 17 \\
\hline Output 2 & CCA1 & CCA2 & CCA3 \\
\hline Eigenvalue & 0.655 & 0.415 & 0.295 \\
Proportion Explained & 0.174 & 0.11 & 0.078 \\
Cumulative Proportion & 0.174 & 0.284 & 0.362 \\
\hline Output 3 & $\mathbf{C C A 1}$ & $\mathbf{C C A 2}$ & $\mathbf{C C A 3}$ \\
\hline pH & -0.089 & 0.106 & -0.362 \\
$\mathrm{CaCO} \%$ & 0.003 & 0.132 & -0.335 \\
Org C\% & -0.199 & $0.626 * *$ & -0.131 \\
$\mathrm{~N} \%$ & -0.088 & $0.762^{*}$ & -0.05 \\
$\mathrm{C} / \mathrm{N}$ & $-0.415 *$ & -0.234 & -0.052 \\
$\mathrm{AWC}(\mathrm{mm})$ & 0.289 & $-0.457^{* *}$ & 0.074 \\
$\mathrm{H}$ & $-0.409 *$ & 0.348 & -0.27 \\
$\mathrm{~L}$ & -0.184 & $0.912^{* *}$ & -0.156 \\
$\mathrm{~T}$ & $-0.641 * *$ & 0.635 & 0.03 \\
$\mathrm{~F}$ & $0.522^{*}$ & $-0.756^{* *}$ & 0.04 \\
$\mathrm{R}$ & 0.181 & 0.181 & $-0.802^{*}$ \\
$\mathrm{~N}$ & $0.733^{* *}$ & -0.519 & 0.041 \\
\hline
\end{tabular}

than the means of sub-clusters $\mathrm{II}^{\circ} \mathrm{a}, \mathrm{II}^{\circ} \mathrm{b}$, $\mathrm{II}^{\circ} \mathrm{c}$. Furthermore, sub-cluster $\mathrm{I}^{\circ} \mathrm{a}$ showed a $\mathrm{N}$-indicator mean significantly lower $(\mathrm{DF}=$ 4 , $\mathrm{SS}=4.98 ; \mathrm{F}=3.38, \mathrm{P}<0.024)$ than the mean of sub-clusters $\mathrm{II}^{\circ} \mathrm{a}, \mathrm{II}^{\circ} \mathrm{b}$ and $\mathrm{II}^{\circ} \mathrm{c}$.

\section{$C C A$}

Results of the CCA analysis on the matrix of 30 relevés, 130 species and 12 variables confirmed the differences between the two main clusters previously identified (Tab. 3, Fig. $4 \mathrm{a}$ and Fig. $4 \mathrm{~b}$ ) . The first CCA axis accounted for $66 \%$ of the total variance and was highly correlated $(\mathrm{P}<0.01)$ with the ecoindicators for $\mathrm{N}(r=0.73)$ and $\mathrm{T}(r=-0.64)$; it was also correlated $(\mathrm{P}<0.05)$ with $\mathrm{F}$ $(r=0.52)$ and $\mathrm{H}(r=-0.41)$ indicators, as well as with the ratio $\mathrm{C} / \mathrm{N}(r=-0.42)$.

The second CCA axis accounted for $42 \%$ of the total variance and showed a highly significant $(\mathrm{P}<0.01)$ correlation with $\mathrm{L}$ $(r=0.91)$ and $\mathrm{F}(r=-0.76)$ ecoindicators; it was also correlated $(\mathrm{p}<0.01)$ with organic carbon $(r=0.63)$ and with measured nitrogen $(r=0.76)$. The third axis accounted for $29 \%$ of the variance in the dataset and showed a significant correlation $(\mathrm{p}<0.05)$ with the $\mathrm{R}$ indicator $(r=-0.80)$.

A small group of species exclusive of cluster $I^{\circ}$ was projected onto two branches of CCA plane (Fig. 4): on the bottom left of the scattergram, species with large abundance or exclusive presence in the sub-cluster $\mathrm{I}^{\circ} \mathrm{a}$ (like Quercus ilex, Viburnum tinus, Aegilops geniculata, Lotus ornithopodioides and Polypodium cambricum) are displayed; on the right top of the same plot, species largely 


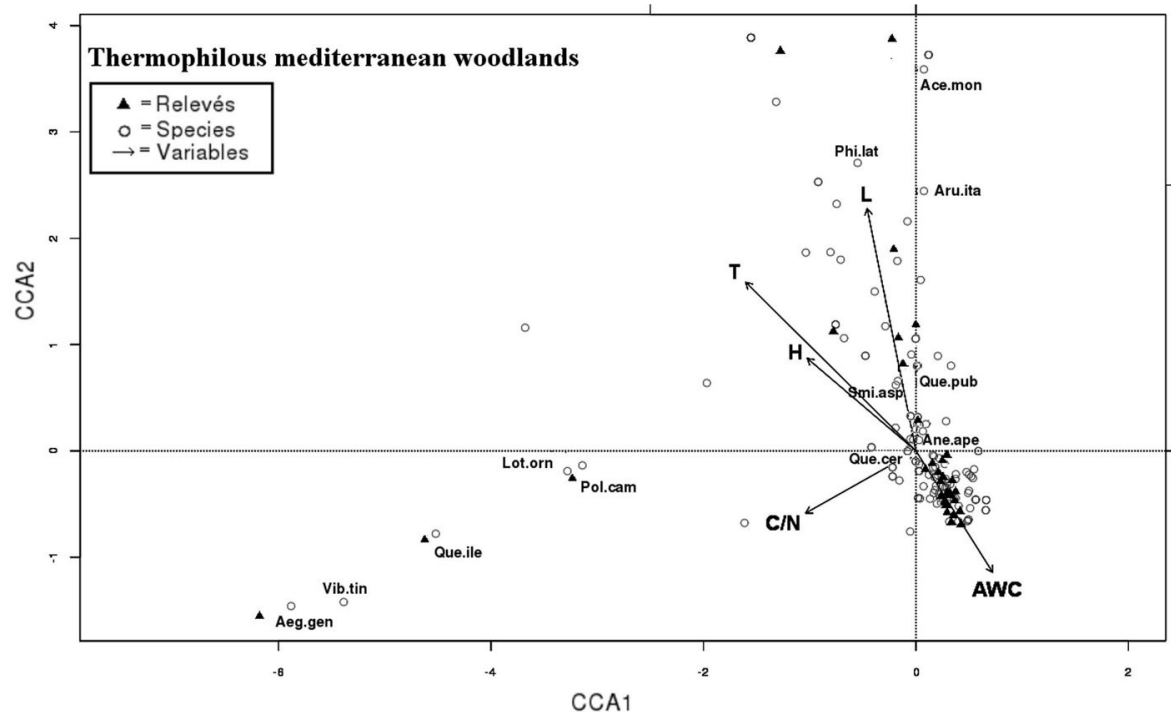

Fig. 4 - CCA triplot according to axes 1 and 2: species, relevés and variables of thermophilous Mediterranean woodlands (cluster $I^{\circ}$ ) are projected into two branches on the bottom left (sub-cluster $I^{\circ} a$ ) and on the top left (sub-cluster $I^{\circ} b$ ). Most representing species are indicated with labels (see Tab. S2 in Appendix 1 for species abbreviations) and most correlated soil parameters are displayed.

abundant in the sub-cluster $\mathrm{I}^{\circ} \mathrm{b}$ may be found, such as Acer monspessulanum, Cercis siliquastrum, Quercus pubescens, Smilax aspera, Arum italicum.

In the central sector of CCA (Fig. 5), the cloud of species projected in the direction of AWC, $\mathrm{F}$ and $\mathrm{N}$ indicators belongs to the $\mathrm{II}^{\circ}$ cluster and corresponds to meso-hygrophilous woodlands dominated by Quercus cerris with the exclusive occurrence of Quercus frainetto and Quercus robur. All the species belonging to cluster $\mathrm{II}^{\circ}$ (like Sambucus nigra, Corylus avellana, Acer obtusatum, Cornus, sanguinea, Symphytum officinale, Ra-

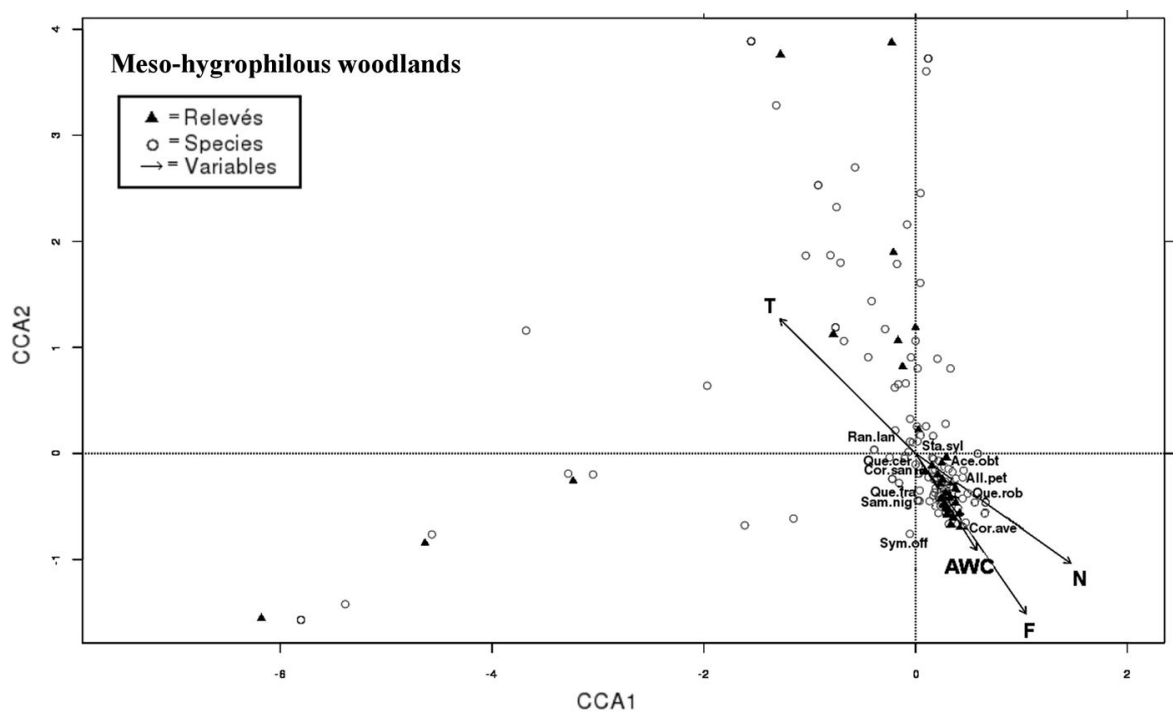

Fig. 5 - CCA triplot according to axes 1 and 2: species, relevés and variables of meso-hygrophilous woodlands (cluster $\mathrm{II}^{\circ}$ ) are projected in the centre of axes plane. Most representing species are indicated by labels (see Tab. S1 in Appendix 1 for species abbreviations) and most correlated variables are displayed.

\section{Discussion}

The results from the canonical correspondence analysis carried out may be easily interpreted based on the ecoindicator values used in this study. Species of the meso-hygrophilous woodlands (cluster $\mathrm{II}^{\circ}$ ) were distributed along the gradients of water and nutrients, as revealed by their $\mathrm{F}$ and $\mathrm{N}$ indicator values, as well as by the measured soil AWC parameter. In fact, water and nutrients represent the key factors responsible for survival of forest patches dominated by Quercus frainetto and Quercus robur on deep soils with the highest water availability (Göransson et al. 2006). In the investigated area the above communities occur on plain surfaces, as well as on the steep slopes of the ditches, on plio-pleistocenic marine sediments and on tuffs (Tab. 2).

Shrublands and open woodlands of Quercus pubescens and Quercus cerris (subcluster $\mathrm{I}^{\circ} \mathrm{b}$ ) were distributed along the maximum variation of the $\mathrm{T}, \mathrm{L}$ and $\mathrm{H}$ indicators (Fig. 4). $\mathrm{T}$ and $\mathrm{H}$ indicators were significantly correlated with CCA axis 1 , while $\mathrm{L}$ indicator with CCA axis 2 (Tab. 3). Soils in the above communities are lithic and shallow, with low AWC values (Tab. 2). The above evidence indicate that light, temperature and disturbance are the key factors shaping these communities, mostly occurring on calcareous bedrocks.

As clearly revealed by the CCA triplot in Fig. 4, a small group of species dominated by Quercus ilex and Viburnum tinus are related with the highest $\mathrm{C} / \mathrm{N}$ ratio values in the dataset. The above result can partly be explained by the slower decomposition rate of the sclerophyllous leaves leading to a consistent accumulation of organic carbon in these communities (Giordano 2002, Xamena et al. 1991).

Through the correlation of CCA axes with species and variables (Fig. 4, Fig. 5, Tab. 3) it was possible to identify two different types of habitats, corresponding to the clusters $\mathrm{I}^{\circ}$ and $\mathrm{II}^{\circ}$ :

1. a core habitat (cluster $\mathrm{II}^{\circ}$ ) represented by patches of temperate forest with higher diversity in species as well as in landforms and lithotypes, supported by high water and nutrients availability (Perakis \& Hedin 2001);

2. an ecotonal habitat (cluster $\mathrm{I}^{\circ}$ ) characterized by mixed evergreen and thermophilous deciduous oak forest depending on light, temperature and human disturbance, on soils with the lowest AWC values (Tab. $1)$.

The above habitats were distributed along three multi-composite gradients identified by CCA: (i) soil moisture and nutrients $(\mathrm{F}, \mathrm{N}$ indicators, AWC); (ii) light and temperature ( $\mathrm{L}, \mathrm{T}$ indicators); and (iii) disturbance $(\mathrm{H}$ indicator). Soil AWC was the main factor summarizing the complexity of the vegetation 
gradients investigated, as well as the species and communities distribution in the two habitats. Indeed, large differences in soil AWC were detected among species assemblages characterized by high environmental heterogeneity of landforms, substrates and soils (Testi et al. 2004, Oswalt et al. 2006, Murata et al. 2009). AWC also showed marked differences among community structures (Tab. 1 ): from more mature and complex communities with closed canopy of the core habitat (cluster $\mathrm{II}^{\circ}$ ) to younger ones with tendency towards open woodlands of the ecotonal habitat (cluster $\mathrm{I}^{\circ}$ ).

Among the soil parameters measured in this study, AWC was the most efficient for the description of vegetation changes, being an aggregate set of more than one variable, such as organic matter, sand, silt and soil depth, and therefore summarizing soil characteristics at the community scale (Wilson et al. 2001). Among EIVs, light (L) and nutrients $(\mathrm{N})$ were the main factors responsible for structuring communities and determining species assemblage: higher $\mathrm{N}$ values were associated to more mature and complex meso-hygrophilous communities, while higher $\mathrm{L}$ values were linked to younger thermophilous woodlands.

In the Mediterranean environments anthropic disturbance affects mainly the meso-hygrophilous vegetation in respect to the more resilient thermo-xerophilous communities (Lucchese \& Pignatti 1990, Hill et al. 2002) For this reason, the persistence of the mesohygrophilous vegetation of the core habitat within an area historically affected by human activities is particularly valuable. The conservation of these patches of humid vegetation was favored not only by the peculiar geomorphology of some sites (ditches) in the Reserve, but also by water and nutrients availability (Fig. 5). For the above reasons, conservation activities aimed at preservation of the core habitat should be adopted, including the realization of ecological corridors connecting the different patches of habitat (Diamond 1972, Newmark 1987, Testi et al. 1996), and the conservation of soil nutrients and water regime to prevent soil fertility losses and erosion (Godefroid et al. 2007).

Our study highlights the importance of protecting the more vulnerable core habitat, keeping a light and controlled sheep grazing only on the edges of the thermophilous woodlands which are historically adapted to disturbance (Naveh 1987). The protection must be on a local scale, where the key ecological factors emerged from the multiple set of indicators and parameters (Niemela et al. 1996, Keddy 2005, Chávez \& Macdonald 2010)

\section{Conclusion}

Multi-dimensional data analysis may help in the identification of key factors underlying the ecosystem complexity (Lalanne et al. 2010). In this study, the combined use of soil parameters and plant ecoindicators allowed to detect differences and similarities among the investigated communities at a fine scale.

Our results showed the ability of light (L) and soil nutrients $(\mathrm{N})$ indicators and of soil measured parameter AWC to detect differences in ecological requirements of species and communities (Testi et al. 2004, 2009). AWC resulted a good synthetic soil parameter able to detect this diversity of gradients, species and communities, confirming the results of previous researches in the Mediterranean environments (Testi et al. 2004, Piccolo et al. 1996).

\section{References}

Angermeier PL, Karr JR (1994). Biological integrity versus biological diversity as policy directives: protecting biotic resources. BioScience 44: 690-697. - doi: 10.2307/1312512

Anonymous (1993). Guide geologiche nazionali: Lazio. Società Geologica Italiana, Roma, Italy, pp. 368. [in Italian]

Benbi DK, Brar JS (2009). A 25-year record of carbon sequestration and soil properties in intensive agriculture. Agronomy for Sustainable Development 29 (2): 257-265. - doi: 10.1051/ agro:2008070

Borhidi A (1995). Social behaviour types, the naturalness and relative ecological indicator values of the higher plants in the Hungarian flora. Acta Botanica Hungarica 39: 97-181.

Braun-Blanquet J (1932). Plant sociology. McGraw-Hill, New York, USA, pp. 439.

Cairns J, McCormick PV, Niederlehner BR (1993). A proposed framework for developing indicators of ecosystem health. Hydrobiologia 236: 1-44. - doi: 10.1007/BF00006084

Celesti Grapow L, Pignatti E, Pignatti S (1993). Ellenbergs Zeigerwerte zur ökologischen Bewertung der archäologischen Zonen in Rom. Phytocoenologia 23: 291-299.

Chávez V, Macdonald S (2010). The influence of canopy patch mosaics on understory plant community composition in boreal mixedwood forest. Forest Ecology and Management 259 (6): 1067 1075. - doi: 10.1016/j.foreco.2009.12.013

Costantini EAC (2007). Linee guida dei metodi di rilevamento e informatizzazione dei dati pedologici. CRA-ABP, Firenze, Italy, pp. 282. [in Italian]

Daniels WL, Haering KC, Galbraith JM (2004). Mine soil morphology and properties in pre- and post-SMCRA coal mined landscapes in Southwest Virginia. In: Proceedings of the "National Meeting of the American Society of Mining and Reclamation". Lexington (KY, USA) 18-24 April 2004. ASMR, Lexington, KY, USA, pp. 421-449.

Diamond JM (1972). Biogeographic kinetics: estimation of relaxation times for avifaunas of southwest Pacific islands. Proceedings of the Na- tional Academy of Sciences USA 69 (11): 31993203. - doi: 10.1073/pnas.69.11.3199

Diekmann M (1995). Use and improvement of Ellenberg's indicator values in deciduous forests of the Boreo-nemoral zone in Sweden. Ecography 18: 178-189. - doi: 10.1111/j.1600-0587.1995. tb00339.x

Dowgiallo G, Vannicelli L (1993). Edaphic characteristics of mixed Quercus cerris communities in Latium. Annali di Botanica 51: 53-75.

Ellenberg H (1974). Indicator values of vascular plants in Central Europe. Scripta Geobotanica 9: 1-122.

Ellenberg H, Weber HE, Düll R, Wirth V, Werner W, Paulißen D (1992). Zeigerwerte von Pflanzen in Mitteleuropa. Datenbank. Scripta Geobotanica 18: $1-258$.

Ewald W (2003). Invasive plants of the world. CABI Publishing, CAB International, Wallingford, UK, pp. 548.

Fanelli G, De Lillis M (2004). Relative growth rate and hemerobiotic state in the assessment of disturbance gradients. Applied Vegetation Science 7 (1): 133-140. - doi: 10.1111/j.1654-109X 2004.tb00603.x

Fanelli G, Testi A (2008). Detecting large and fine scale patterns of disturbance in towns by means of plant species inventories: maps of hemeroby in the town of Rome - In: "Urbanization: $21^{\text {st }}$ Century Issues and Challenges". Nova Publisher, NY, USA, pp. 197-211.

Fanelli G, Tescarollo P, Testi A (2006a). Ecological indicators applied to urban and suburban flora. Ecological Indicators 6: 444-457. - doi: 10.1016/j.ecolind.2005.06.002

Fanelli G, Testi A, Pignatti S (2006b). Ecological indicator values for species in Central and Southern Italy flora. In: "Il Sistema Ambientale della Tenuta Presidenziale di Castelporziano. Ricerche sulla complessità di un ecosistema forestale costiero mediterraneo". Accademia delle Scienze, "Scritti e Documenti" XXXVII, Seconda Serie, Vol. II, pp. 505-564. [in Italian] Fanelli G, Pignatti S, Testi A (2007). An application case of ecological indicator values (Zeigerwerte) calculated with a simple algorithmic approach. Plant Biosystems 141: 15-21. - doi: 10.1080/11263500601153685

Feng G, Sharratt B, Vaughan J, Lamb B (2009). A multiscale database of soil properties for regional environmental quality modelling in the western United States. Journal of Soil and Water Conservation 64: 363-373. - doi: 10.2489/jswc.64.6.363 Gary MO, Sharp JM, Caramanna G, Havens RS (2003). Volcanically influenced speleogenesis: forming El Sistema Zacatón, Mexico, and Pozzo Merro, Italy, the deepest phreatic sinkholes in the world. Geological Society of America, Abstracts with Programs, pp. 35.

Gillet F (2000). La Phytosociologie synusiale intégrée - Guide méthodologique. Docu. Labo. Ecol. Vég. Université de Neuchatel - Institut de Botanique 1, Neuchatel, Switzerland, pp. 68.

Giordano A (2002). Pedologia forestale e conservazione del Suolo, Edizioni UTET, Torino, Italy, pp. 600. [in Italian] 
Godefroid S, Monbaliu D, Koedam N (2007). The role of soil and microclimatic variables in the distribution patterns of urban wasteland flora in Brussels, Belgium. Landscape and Urban Planning 80: 45-55. - doi: 10.1016/j.landurbplan. 2006.06.001

Goslee SC, Urban DL (2007). The ecodist package for dissimilarity-based analysis of ecological data. Journal of Statistical Software 22: 7. [online] URL: http://www.jstatsoft.org/v22/i07/paper/

Greuter W, Burdet HM, Long G (1984). MedChecklist, 1.3.4, Genève, Switzerland. [online] URL: http://ww2.bgbm.org/mcl/home.asp.

Grime JP, Hodgson JG, Hunt R (1988). Comparative plant ecology. Unwin-Hyman, London, UK, pp. 762.

Göransson H, Wallander H, Ingerslev M, Rosengren U (2006). Estimating the relative nutrient uptake from different soil depths in Quercus robur, Fagus sylvatica and Picea abies. Plant and Soil 286 (1-2): 86-97. - doi: 10.1007/ s11104-006-9028-0

Hawkes JC, Pyatt DG, White IM (1997). Using Ellenberg indicator values to assess soil quality in British forests from ground vegetation: a pilot study. The Journal of Applied Ecology 34 (2): 375. - doi: $10.2307 / 2404883$

Hill MO, Roy DB, Thompson K (2002). Hemeroby, urbanity and ruderality: bioindicators of disturbance and human impact. Journal of Applied Ecology 39 (5): 708-720. - doi: 10.1046/j.13652664.2002.00746.x

Hillebrand H (2005). Regressions of local on regional diversity do not reflect the importance of local interactions or saturation of local diversity. Oikos 110: 195-198. - doi: 10.1111/j.0030-1299. 2005.14008.x

Jones MLM, Hayes F, Mills G, Sparks TH, Fuhrer J (2007). Predicting community sensitivity to ozone using Ellenberg Indicator values. Environmental Pollution 146: 744-753. - doi: 10.10 16/j.envpol.2006.03.035

Kaiser T, Käding H (2005). Proposal for a transformation scale between bioindicatively determined water supply levels of grassland sites and mean moisture indicator values according to Ellenberg. Archives of Agronomy and Soil Science 51 (3): 241-246. - doi: 10.1080/036503405000 77836

Keddy P (2005). Putting the plants back into plant ecology: six pragmatic models for understanding and conserving plant diversity. Annals of Botany 96 (2): 177-189. - doi: 10.1093/aob/mci166

Kowarik I (1990). Some responses of flora and vegetation to urbanization in Central Europe. In: "Urban ecology: plants and plant communities in urban environments" (Sukopp H, Hejny S, Kowarik I eds). SPB Academic Publishing, Amsterdam, the Netherlands, pp. 45-74.

Lalanne A, Bardat J, Lalanne-Amara F, Ponge JF (2010). Local and regional trends in the ground vegetation of beech forests. Flora - Morphology, Distribution, Functional Ecology of Plants 205: 484-498. - doi: 10.1016/j.flora.2009.12.032

Legendre P, Legendre L (1998). Numerical eco- $\operatorname{logy}\left(2^{\text {nd }}\right.$ edn). Elsevier Science BV, Amsterdam, The Netherlands, pp. 880

Lucchese F, Pignatti S (1990). Sguardo sulla vegetazione del Lazio Marittimo. Quaderni Accademia Nazionale dei Lincei 264: 5-48. [in Italian]

Maechler M (2012). Cluster analysis extended Rousseeuw et al. (v. 1.14.4). [online] URL: http://cran.r-project.org/web/packages/cluster/index.html

Martinis B (1992). L'evoluzione della dorsale tiberina (Lazio centrale). Rendiconti Lincei 3 (2): 97-107. [in Italian]

MIPAF (2000). Metodi di analisi chimica del suolo. Ministero delle Politiche Agricole e Forestali, Franco Angeli Editore, Rome, Italy, pp. 536. [in Italian]

Murata N, Ohta S, Ishida A, Kanzaki M, Wachirinrat C, Artchawakom T, Sase H (2009). Comparison of soil depths between evergreen and deciduous forests as a determinant of their distribution, Northeast Thailand. Journal of Forest Research 14 (4): 212-220. - doi: 10.1007/s10310009-0127-7

Naveh Z (1987). Landcape ecology, management and conservation of European and Levant Mediterranean uplands. In: "Functional analysis in Mediterranean ecosystems" (Tenhunen JD, Catarino FM, Lange OL, Oechel WC eds). Springer, Berlin, Germany, pp. 641-657.

Newmark WD (1987). A land-bridge islands perspective on mammalian extinctions in western North American Parks. Nature 325: 430-432. doi: $10.1038 / 325430 \mathrm{a} 0$

Niemela J, Haila Y, Punttila P (1996). The importance of small-scale heterogeneity in boreal forests: variation in diversity in forest-floor invertebrates across the succession gradient. Ecography 19(8): 352-368. - doi: 10.1111/j.16000587.1996.tb01264.x

Oksanen J, Kindt R, Legendre P, O'Hara RB (2012). Package "vegan" - Ordination methods, diversity analysis and other functions for community and vegetation ecologists. [online] URL: http://vegan.r-forge.r-project.org/

Oswalt SN, Brandeis TJ, Dimick BP (2006). Phytosociology of vascular plants on an international biosphere reserve: Virgin Islands National Park. Caribbean Journal of Sciences 42: 53-66. [online] URL: http://caribjsci.org/april06/42_5366.pdf

Perakis SS, Hedin LO (2001). Fluxes and fates of nitrogen in soil of an unpolluted old-growth temperate forest, southern Chile. Ecology 82 (8): 2245-2260. - doi: 10.1890/0012-9658(2001) 082[2245:FAFONI]2.0.CO;2

Piccolo A, Pietramellara G, Mbagwu JSC (1996). Effects of coal derived humic substances on water retention and structural stability of Mediterranean soils. Soil Use and Management 12: 209213. - doi: 10.1111/j.1475-2743.1996.tb00545.x Pignatti S (1982). Flora d'Italia. Edagricole, Bologna, Italy, pp. 2324. [in Italian]

Pignatti S (2005). Biondicazione attraverso le piante vascolari. Valori di indicazione secondo Ellenberg (Zeigerwerte) per le specie della Flora
d'Italia. Braun-Blanquetia 39: 1-97. [in Italian] Pignatti S, Bianco PM, Fanelli G, Guarino R, Petersen J, Tescarollo P (2001). Reliability and effectiveness of Ellenberg's indices in checking flora and vegetation changes induced by climatic variations. In: "Fingerprints of climate changes: adapted behaviour and shifting species ranges" (Walter JR, Burga CA, Edwards PJ eds). Kluwer Academic Publishing, New York, USA and Plenum Publisher, London, UK, pp. 281-304.

Podani J (2007). Analisi ed esplorazione multivariata dei dati in ecologia e biologia. Liguori Editore srl, Naples, Italy, pp. 544. [in Italian]

Pärtel M, Zobel M, Zobel K, van der Maarel E (1996). The species pool and its relation to species richness: evidence from Estonian plant communities. Oikos 75: 111-117. - doi: 10.2307/354 6327

Pärtel M, Kalamees R, Zobel M, Rosén E (1999). Alvar grasslands in Estonia: variation in species composition and community structure. Journal of Vegetation Science 10 (4): 561-570. - doi: 10.23 07/3237190

R Development Core Team (2012). The R Project for Statistical Computing. Web Site. [online] URL: http://www.r-project.org/

Roo-Zielinska E, Solon J (1988). Phytosociological typology and bioindicator values of plant communities, as exemplified by meadows in the Nina valley, Southern Poland. Documents Phytosociologiques 11: 543-554.

Salter PJ, Williams JB (1969). The influence of texture on the moisture of soils: relationships between particle size composition and moisture content at the upper and lower limits of available water. Journal of Soil Science 20 (1): 126131. - doi: 10.1111/j.1365-2389.1969.tb01561.x Schaffers AP, Sýkora KV (2000). Reliability of Ellenberg indicator values for moisture, nitrogen and soil reaction: a comparison with field measurements. Journal of Vegetation Science 11 (2): 225-244. - doi: 10.2307/3236802

Schimel JP, Bennet J (2004). Nitrogen mineralization: challenges of a changing paradigm. Eco$\operatorname{logy} 85$ : 591-602. - doi: 10.1890/03-8002

Schmidtlein S, Ewald J (2003). Landscape patterns of indicator plants for soil acidity in the Bavarian Alps. Journal of Biogeography 30 (10): 1493-1503. - doi: 10.1046/j.1365-2699.2003.00 879. $\mathrm{x}$

Southall EJ, Dale MP, Kent M (2003). Spatial and temporal analysis of vegetation mosaics for conservation: poor fen communities in a Cornish valley mire. Journal of Biogeography 30 (9): 1427-1443. - doi: 10.1046/j.1365-2699.2003.00 924.x

Testi A, Napoleone I, Cigni A (1996). Floristic and phytogeographical diversity in some protected areas in Italy. Ecologia Mediterranea 22 (34): $81-100$

Testi A, Panzarasa S, Guidi A (2000). La riserva naturale "Macchia di Gattaceca e Macchia del Barco" nel Lazio: un'importante area forestale di contatto tra la vegetazione mediterranea e balcanica. Linea Ecologica 6: 35-42. [in Italian]

Testi A, Crosti R, Dowgiallo G, Tescarollo P, De 
Nicola C, Guidotti S, Bianco PM, Serafini Sauli A (2004). Soil water availability as a discriminant factor in forest vegetation: preliminary results on sub-coastal mixed oak woodlands in central-southern Latium (Central Italy). Annali di Botanica 4: 49-64.

Testi A, Cara E, Fanelli G (2006). An example of realization of Gis ecological maps derived from Ellenberg indicator values in the Biological Reserve of Donana National Park (Spain). Rendiconti Accademia dei Lincei 9: 1-17.

Testi A, De Nicola C, Dowgiallo G, Fanelli G (2009). Correspondences between plants and soil/environmental factors in beech forests of Central Apennines: from homogeneity to complexity. Rendiconti Lincei 21: 27-43. - doi 10.1007/s12210-009-0054-8

Testi A, Fanelli G, Crosti R, Castigliani V, D'Angeli D (2012). Characterizing river habitat quality using plant and animal bioindicators: a case study of Tirino River (Abruzzo Region, Central Italy). Ecological Indicators 20: 24-33. - doi: 10.1016/j.ecolind.2012.01.027

Thimonier A, Dupouey JL, Bost F, Becker M (1994). Simultaneous eutrophication and acidification of a forest ecosystem in North-East France. New Phytologist 126 (3): 533-539. - doi 10.1111/j.1469-8137.1994.tb04252.x

USDA (2010). Keys to soil taxonomy (11 ${ }^{\text {th }}$ edn). USDA, Natural Resources Conservation Service, pp. 346. [online] URL: ftp://ftp-fc.sc.egov.usda. gov/NSSC/Soil_Taxonomy/keys/2010_Keys_to_ Soil_Taxonomy.pdf

Van der Maarel E (1975). Man-made natural ecosysems in environmental management and planning. In: "Unifying concepts in ecology" (van Dobben WH, McConnel L eds). Junk, The Hague, Pudoc, Wageningen, The Netherlands, pp. 263-274.

Van der Maarel E, Boot R, van Dorp D, Rijntjes J (1985). Vegetation succession on the dunes near Oostvoorne, The Netherlands: a comparison of the vegetation in 1959 and 1980 . Vegetatio 58: 137-187. - doi: 10.1007/BF00163874

Vevle O, Aase K (1980). On the use of ecological factor numbers in Norwegian forest communities. Norske Videnskap Selskovo Rapport Botaniska Serie 5: 178-201. [in Norwegian]

Westhoff V, Van der Maarel E (1978). The Braun-Blanquet approach. In: "Classification of plant communities" (Whittaker RH ed). Junk, The Hague, The Netherlands, pp. 287-399.

Wilson S, Pyatt D, Malcolm D, Connolly T (2001). The use of ground vegetation and humus type as indicators of soil nutrient regime for an ecological site classification of British forests. Forest Ecology and Management 140 (2-3): 101116. - doi: 10.1016/S0378-1127(00)00318-2

Xamena J, Garcia C, Morey M (1991). Quercus ilex L. litter decomposition and mineral evolution in an evergreen oak woodland in Majorca (Balearic islands, Spain). In. "Responses of forest ecosystems to environmental changes" (Teller A, Mathy P, Jeffers JNR eds). Elsevier Sciences Publishers Ltd., Oxford, UK, pp. 865866.

\section{Supplementary Material}

\section{Appendix 1}

Tab. S1 - Values of soil parameters and ecoindicators reported for each vegetation relevé and soil profile.

Tab. S2 - Species coverage in the subclusters expressed as percentage values.

Link: Sicuriello_963@supp1001.pdf 